\title{
Chromosome numbers of invasive and potentially invasive species in the flora of the Republic of Altai. IV
}

\author{
E. Yu. Zykova' ${ }^{1,2 *}$, T. V. An'kova ${ }^{1,3}$, M. N. Lomonosova $a^{1,4}$ \\ ${ }^{1}$ Federal State Institution of Science Central Siberian Botanical Garden of Siberian Branch of RAS, \\ Zolotodolinskaya str., 101, Novosibirsk, 630090, Russian Federation \\ ${ }^{2}$ E-mail: elena.yu.zykova@gmail.com; ORCID iD: https://orcid.org/0000-0002-1847-5835 \\ ${ }^{3}$ ORCID iD: https://orcid.org/0000-0003-3661-0719 \\ ${ }^{4}$ ORCID iD: https://orcid.org/0000-0003-0510-5349 \\ *Corresponding author
}

Keywords: Asteraceae, Brassicaceae, Caryophyllaceae, chromosome studies, Fabaceae, flow cytometry, genome size, Malvaceae, Oxalidaceae, Poaceae, Solanaceae, species distribution.

Summary. Chromosome numbers $(2 n)$ in 10 invasive and potentially invasive plant species from the families Asteraceae, Brassicaceae, Caryophyllaceae, Fabaceae, Malvaceae, Oxalidaceae, Poaceae and Solanaceae are reported on the samples collected in the Republic of Altai. To determine the ploidy levels, we used methods of direct chromosome counting and flow cytometry in some cases. Among them, chromosome complements were first examined in Russia for Eruca vesicaria subsp. sativa $(2 n=22)$. Psammophiliella muralis $(2 n=34)$, Medicago sativa subsp. varia $(2 n \approx$ $32 ; 2 \mathrm{C}=4.8 \mathrm{pg})$ and Solanum nigrum $(2 n=48)$ were first studied from Siberia. Malva verticillata $(2 n=42)$, Oxalis dillenii $(2 n=24)$, Lolium perenne $(2 n=14)$ and Setaria faberi $(2 n=36)$ were first studied from the Republic of Altai. Tetraploid cytotype and genome size of Picris hieracioides $(2 n=4 x=20 ; 2 \mathrm{C}=8.89 \mathrm{pg})$ were discovered for the first time. Common distribution and the history of floristic findings of these species in the Republic of Altai are given. Previously published data on chromosome numbers from Russia are cited.

\section{Числа хромосом инвазивных и потенциально инвазивных видов во флоре Республики Алтай: сообщение 4}

\author{
Е. Ю. Зыкова, Т. В. Анькова, М. Н. Ломоносова
}

Федеральное государственное бюджетное учреждение науки «Центральный сибирский ботанический сад» Сибирского отделения РАН, ул. Золотодолинская, 101, г. Новосибирск, 630090, Россия

Ключевые слова: кариологическое изучение, проточная цитометрия, размер генома, расселение видов, Аsteraceae, Brassicaceae, Caryophyllaceae, Fabaceae, Malvaceae, Oxalidaceae, Poaceae, Solanaceae.

\footnotetext{
Аннотация. Приводятся данные о числах хромосом $(2 n)$ для 10 инвазивных и потенциально инвазивных видов из семейств Asteraceae, Brassicaceae, Caryophyllaceae, Fabaceae, Malvaceae, Oxalidaceae, Poaceae, Solanaсеае, полученные на материале из Республики Алтай. Для определения уровня плоидности использован метод прямого подсчета хромосом, а для Medicago sativa subsp. varia и Picris hieracioides метод проточной цитометрии (FCM). Впервые для России определено число хромосом у Eruca vesicaria subsp. sativa $(2 n=22)$, впервые для Сибири - у Psammophiliella muralis $(2 n=34)$, Medicago sativa subsp. varia $(2 n \approx 32 ; 2 \mathrm{C}=4.8$ пг), Solanum
} 
nigrum $(2 n=48)$, впервые для Республики Алтай - у Malva verticillata $(2 n=42)$, Oxalis dillenii $(2 n=24)$, Lolium perenne $(2 n=14)$ и Setaria faberi $(2 n=36)$. Впервые обнаружен тетраплоидный цитотип и определен размер генома у Picris hieracioides $(2 n=4 x=20 ; 2 \mathrm{C}=8.89$ пг). Для всех исследованных видов приводятся сведения по общему распространению, истории флористических находок и расселению на территории Республики Алтай, а также литературные данные по числам хромосом с территории России.

We continue the karyological study of invasive and potentially invasive species in the flora of Southern Siberia on the example of the Republic of Altai (Lomonosova et al., 2018; Zykova et al., 2018, 2020), one of the most popular touristic regions of Siberia. This paper provides information about 11 species that are active in the republic, four of which are included in the list of invasive or potentially invasive species of Siberia (Ebel et al., 2014). The information on the history of floristic studies of examined species in the territory of the Republic of Altai is provided here. Considering the distribution of species in the Republic of Altai, we refer to the northern regions: Gorno-Altaysk, Mayma, Choya, Turochak and Chemal; to the Central regions: Onguday, Ust'-Kan, Shebalino, Ust'-Koksa and to the South-Eastern regions: Ulagan and Kosh-Agach. For all species, the references on chromosome numbers revealed from the samples collected in Russia are given as well, as relevant information in the international database "The Chromosome Counts Database" (Rice et al., 2015) is reflected incompletely. Latin names of plants are given according to the "Catalog of Life" (Hassler, 2020).

The chromosome numbers were determined by direct counting in metaphase on root meristem squash preparations. Seeds were germinated on sterile sand. The root tips were pretreated for two hours with $0.2 \%$ colchicine water solution, fixed in $3: 1$ absolute ethanol-glacial acetic acid and stained with $1 \%$ acetic hematoxylin. Metaphase plates were observed under $100 \times$ magnification by the Axioscope 40 (Karl Zeiss, Axio Lab) and photographed by the AxiCam MRc 5 digital camera.

The absolute nuclear DNA amount was assessed by flow cytometry using Cy Flow Space cytometer (manufactured by Sysmex Partec, Germany) equipped with a green laser. The sample preparation from dry leaves and FCM procedure followed that of Doležel et al. (2007). As internal standards were used Solanum lycopersicum Stupicke (2C DNA content $=1.96 \mathrm{pg})($ Doležel et al., 1992) for Picris hieracioides and Pisum sativum L. 'Ctirad' $(2 \mathrm{C}=$ $9.09 \mathrm{pg}$ ) (Doležel et al., 1998) for Medicago varia.

The herbarium specimens (vouchers) are deposited in the Herbarium of the Central Siberian Botanical Garden SB RAS (NS).

\section{Inula helenium $\mathrm{L} ., \mathbf{2} n=\mathbf{2 0}$}

"Russian Federation, the Republic of Altai, Turochak district, Altai State Reserve, Yaylu village, along the roads and the streets, $51^{\circ} 46^{\prime} \mathrm{N}, 87^{\circ} 36^{\prime} \mathrm{E}$. 14 VIII 2017. E. Zykova”, Z443-5317 (fig. 1A).

- Perennial. European-Mediterranean-West Asian species (Gubanov, 1994), found in some regions of Siberia. In the Republic of Altai, most likely it is invasive. According to P. N. Krylov (1904), at the beginning of the 20th century the species was not known in Altai. The first localities were recorded in the middle of the 20th century in Mayma, Chemal, Shebalino and Ust'-Kan districts (Krylov, 1949). To date, the species is quite common in the northern regions of the republic; it does not settle in central regions. Occurs in roadsides, wastelands, along the banks of reservoirs.

The same chromosome number was determined from Chechen Republic (Magulaev, 1974), Choya district of the Republic of Altai (Rostovtseva, 1983), Primorye Territory (Probatova, 2014).

Diploid $(2 x), x=10$.

Picris hieracioides L., $2 n=20 ; 2 C=8.89 \pm 0.32$ pg

"Russian Federation, the Republic of Altai, Mayma district, vicinity of Kysyl-Ozek village, quarry at a closed landfill, $51^{\circ} 58^{\prime} \mathrm{N}, 85^{\circ} 55^{\prime} \mathrm{E}$. 15 VIII 2018. E. Zykova", Z691-2418 (fig. 1B).

- Biennial. European-Mediterranean-Central Asian species with a cosmopolitan secondary range (Geltman, 1989). It is common in most regions of Western Siberia, where it is a native species (Lomonosova, 1997). In the Republic of Altai, as invasive species, it was first discovered in the Mayma district in 2008 (Zykova, 2014). Currently, it is rapidly settling in the Mayma and Chemal districts (Zykova, 2015; 2019).

The chromosome number is given for the first time for the Republic of Altai, $2 n=20$ is a new cytotype for the species. $2 n=10$ was determined for the Novosibirsk Region (Krasnikov, Lomonosova, 1990), Irkutsk Region (Probatova et al., 2014a), Primorye Territory (Probatova, 2014).

We have confirmed ploidy level of this species on the base of flow cytometric data. According to 
comprehensive study of Picris hieracioides on the material from 54 populations from Europe (Slovák et al., 2009), the genome size of this species (2Cvalues) at the diploid level varied from $2.26 \mathrm{pg}$ to $3.11 \mathrm{pg}$. Additionally, the authors have discovered one population with plants having $2 \mathrm{C}=4.72 \mathrm{pg}$. The authors assumed that these plants are triploids. Thus, using the direct chromosome count and flow cytometry, we have confirmed tetraploid ploidy level of Altai plants. Siberian populations are needed in further cytogenetic studies.

Tetraploid (4x), $x=5$.

\section{BRASSICACEAE}

Eruca vesicaria subsp. sativa (Mill.) Thell. (E. sativa Mill.), $\mathbf{2 n}=\mathbf{2 2}$

"Russian Federation, the Republic of Altai, Gorno-Altaysk city, brick factory area, outside the flowerbeds, along the fences, $51^{\circ} 58^{\prime} \mathrm{N}, 85^{\circ} 55^{\prime} \mathrm{E} .12 \mathrm{VIII}$ 2018. E. Zykova", Z675-1818.

- Annual. European-Mediterranean-West Asian species with a secondary Eurasian area (Kotov, 1979). It is rare in Siberia; single localities were recorded in the Tomsk and Novosibirsk regions, the Republic of Buryatia (Nikiforova, 1994), and the Altai Territory (Silantyeva, 2013). It was recently discovered in the Republic of Altai (Ebel et al., 2018). The chromosome number was determined for the first time in Russia.

Diploid $(2 x), x=11$.

\section{CARYOPHYLLACEAE}

Psammophiliella muralis (L.) Ikonn., $2 n=34$

"Russian Federation, the Republic of Altai, Turochak district, vicinity of Ust'-Lebed' village, roadside, $52^{\circ} 17^{\prime} \mathrm{N}, 87^{\circ} 20^{\prime}$ E. 8 VIII 2015. E. Zykova", Z794-4015.

- Annual. Euro-Mediterranean species, adventive in Siberia (Ikonnikov, 2004). In the Republic of Altai for a long time it was known only from the vicinity of the village of Choya, Choya district (Kovtonyuk, 1993), by the end of the 20th-beginning of the 21st centuries it was found in Turochak and Mayma districts and in the city of Gorno-Altaysk (Studenikina, 1999; Zykova, Erst, 2012). At present, it is rarely found in these areas in the fields, along the banks of water reservoirs and along roads in settlements (Zykova, 2015).

The chromosome number was determined for the first time on the Siberian material. The same chromosome number was known for the Amur Region (Probatova et al., 2005) and Primorye Territory (Probatova et al., 2017a).

Diploid $(2 x), x=17$.
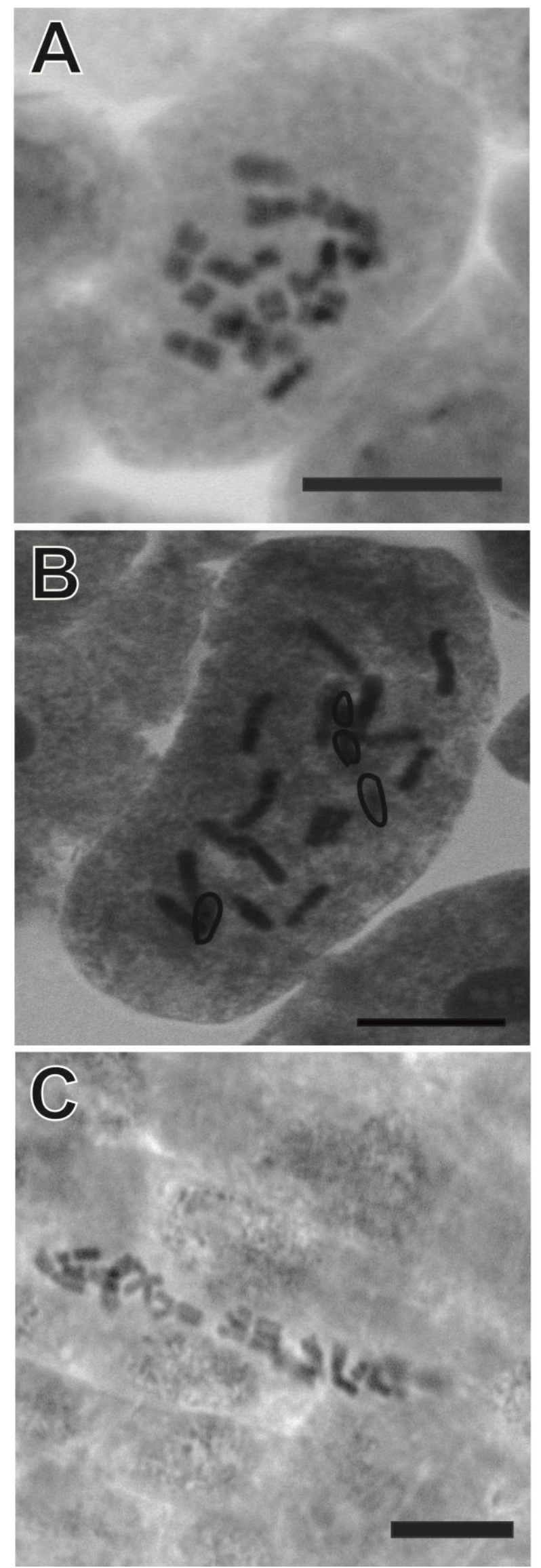

Fig. 1. Mitotic metaphases: A - Inula helenium, $2 n=20$; $\mathrm{B}-$ Picris hieracioides, $2 n=20 ; \mathrm{C}-$ Lolium perenne, $2 n=14$; Scale $=10 \mu \mathrm{m}$. 


\section{FABACEAE}

Medicago sativa subsp. varia (Martyn) Arcang. (M. varia Martyn), $2 n \approx 32,2 \mathrm{C}=\mathbf{4 . 8 0} \pm \mathbf{0 . 1 1} \mathrm{pg}$

"Russian Federation, the Republic of Altai, Gorno-Altaysk city, Lenkina street, the territory of the Gorno-Altaisk University, wasteland, $51^{\circ} 58^{\prime} \mathrm{N}$, 855'ㄹ. 25 VIII 2017. E. Zykova", Z465-7117.

- Perennial. Distributed in Eastern Europe and Kazakhstan (Ebel et al., 2016). It occurs in many Siberian regions and is included in the list of invasive and potentially invasive species of Siberia (Ebel et al., 2014). The first localities in the republic were discovered in 2009 (Zykova, 2015). ow the species is very active in Gorno-Altaysk city and Mayma district, it was recently found in Aktash village of Ulagan district (Ebel et al., 2016).

Previously $2 n=32$ was determined from Khabarovsk Territory (Probatova et al., 2017b).

We ascertained ploidy level of this species using flow cytometric analysis. This data is consistent with previously published for $M$. sativa var. varia (Sakiroglu, Kaya, 2012).

Tetraploid $(4 x), x=8$.

\section{MALVACEAE}

Malva verticillata L. (M. mohileviensis Downar, M. pulchella Bernh.), $2 n=42$

"Russian Federation, the Republic of Altai, Gorno-Altaysk city, Shosseynaya street, wasteland, $51^{\circ} 58^{\prime} \mathrm{N}, 85^{\circ} 55^{\prime}$ E. 22 VIII 2017. E. Zykova", Z7936717.

- Annual. An Asian species, settled in temperate and subtropical regions of the globe, including the most regions of Southern Siberia (Mikhaylova, Ebel, 2016), where it is invasive or potentially invasive species (Ebel et al., 2014). In the Republic of Altai, until the 1990s, it was known in several settlements of the Onguday district, near the mouth of the Bashkaus River in Ulagan district, as well as on the cordons of the Altai Nature Reserve (Zolotukhin, 1983; Vlasova, 1996; Pyak et al., 2000). Over two decades, the species settled in Chemal and Maima districts and in the city of Gorno-Altaysk (Shaulo et al., 2010). At present, it is common along roads, near buildings, on wastelands, in vegetable gardens in the Northern regions of the republic. It is occasionally found in the Central regions and now it penetrates into the South-Eastern ones, where it is a noxious weed of garden crops (Zykova, 2015).

The chromosome number is given for the first time for Western Siberia. The same number is indicated for the Trans-Baikal Territory, Amur Region (Probatova et al., 2012), Irkutsk Region
(Probatova et al., 2014a); $2 n=56$ - for the Irkutsk Region (Probatova et al., 2009); $2 n=84-$ for Primorye Territory (Probatova, 2014).

Hexaploid $(6 x), x=7$.

\section{OXALIDACEAE}

Oxalis dillenii Jacq. (Xanthoxalis stricta (L.) Small), $\mathbf{2 n}=\mathbf{2 4}$

"Russian Federation, the Republic of Altai, Turochak district, Altai State Reserve, cordon Karatash, weed in the yard, $51^{\circ} 46^{\prime} \mathrm{N}, 87^{\circ} 23^{\prime} \mathrm{E}$. 14 VIII 2017. E. Zykova", Z447-5117; "Russian Federation, the Republic of Altai, Mayma district, vicinity of Karlushka village, closed dump, $51^{\circ} 58^{\prime} \mathrm{N}, 85^{\circ} 51^{\prime} \mathrm{E} .18$ VIII 2017. E. Zykova", Z3456417; "Russian Federation, the Republic of Altai, Turochak district, $7 \mathrm{~km}$ from Artybash village, on the bank of the Biya River, near the road, $51^{\circ} 46^{\prime} \mathrm{N}$, $87^{\circ} 15^{\prime}$ E. 18 VIII 2017. E. Zykova”, Z343-5617.

- Annual. A North American species that has spread and naturalized in most parts of the world (Tzvelev, 1996). In Siberia, it has been found since the end of the 20th century (Tzvelev, 1996; Lomonosova, Sukhorukov, 2000). The first localities in the Republic of Altai were found in 2007 in GornoAltaisk city and Mayma district (Ebel, 2008), later in Chemal district (Shaulo et al., 2010). At present, it is common in most northern regions; as a weed it occurs along roads and on wastelands (Zykova, 2015)

The chromosome number is given for the first time for the Republic of Altai. The same number was determined from Primorye Territory (Probatova, 2014), Novosibirsk Region (An`kova et al., 2019).

Tetraploid $(4 x), x=6$.

\section{POACEAE}

\section{Lolium perenne $\mathrm{L}$., $2 n=14$}

"Russian Federation, the Republic of Altai, Turochak district, Yogach village, stadium, $51^{\circ} 46^{\prime} \mathrm{N}$, $87^{\circ} 15^{\prime}$ E. 29 VI 2017. E. Zykova”, Z618-2617 (fig. $1 \mathrm{C})$.

- Perennial. Euro-Mediterranean-West Asian species (Tzvelev, Probatova, 2019). In the beginning of 20th century the species was known in three localities of West Siberia (Krylov, 1928). Currently it is included in the list of invasive and potentially invasive species of Siberia (Ebel et al., 2014). It entered the Republic of Altai in the 2000s, and actively settles in Gorno-Altaysk city, Mayma, Choya and Turochak districts (Zykova et al., 2019). It occurs on wastelands, along roads, on pebbles, in the builtup areas. 
The chromosome number is given for the first time for Western Siberia. The same number was determined from Irkutsk Region (Chepinoga et al., 2010), Republic of Crimea (Petrova, 1968), Krasnodar Territory (Probatova et al., 2009, 2012).

Diploid $(2 x), x=7$.

Setaria faberi R. A. W. Herrm., $2 n=\mathbf{3 6}$

"Russian Federation, the Republic of Altai, Mayma district, vicinity of Mayma village, as a weed near the customs post, $52^{\circ} 02^{\prime} \mathrm{N}, 85^{\circ} 54^{\prime} \mathrm{E}$. 1 VIII 2015. E. Zykova", Z433-3015; "Russian Federation, Altai Territory, Soviet district, Shulgin Log village, streets of the village, by the roads, $52^{\circ} 11^{\prime} \mathrm{N}$, $85^{\circ} 50^{\prime}$ E. 14 VIII 2016. E. Zykova”, Z499-3516.

- Annual. An East Asian species spreading across Eurasia and North America (Shouliang, Phillips, 2006). In Siberia, it was first recorded in the Altai Territory (Pyak et al., 2000). At about the same time, the first locality was found in the Republic of Altai: in the Ulagan district along the Chuisky tract between the mouths of the Boka and Belgebash rivers (Pyak, Ebel, 2001). At present, it is common in the Mayma district and in the city of Gorno-Altaysk (Shaulo et al., 2010; Zykova, 2015); found in the village of Iogach, Turochak district and the village of Myyuta, Shebalino district (Zykova et al., 2019).

The chromosome number is given for the first time for the Republic of Altai. The same chromosome number is indicated for the species from Amur Region (Probatova, Sokolovskaya, 1983), Primorye (Probatova et al., 2014a), Khabarovsk (Probatova et al., 2014b) and Altai (Punina et al., 2013) Territories.

Tetraploid (4x), $x=9$.

\section{SOLANACEAE}

Solanum nigrum L., $2 n=48$

"Russian Federation, the Republic of Altai, Mayma district, vicinity of Karlushka village, closed dump, $51^{\circ} 58^{\prime} \mathrm{N}, 85^{\circ} 51^{\prime} \mathrm{E} .18$ VIII 2017. E. Zykova”,
Z501-6417; "Russian Federation, the Republic of Altai, Gorno-Altaysk city, pebbled riverbank of the Maima River, $51^{\circ} 58^{\prime} \mathrm{N}, 85^{\circ} 55^{\prime} \mathrm{E} .18$ VIII 2017. E. Zykova", Z500-6117.

- Annual. Holarctic species (Poyarkova, 1981). In Siberia, it has been observed since the beginning of the 20th century (Krylov, 1907), in the Republic of Altai - since the forthies of the century (Krylov, 1939; Zolotukhin, 1983). At present, the species is common in the northern and central regions of the republic; it is found near dwellings, in crops, on wastelands and fallow lands, along roads (Zykova, 2015).

This rare cytotype of the species was determined for the first time for Russia. Previously $2 n=60$ was revealed in the Stavropol Territory and Chechen Republic (Magulaev, 1984); $2 n=72$ in the Moscow Region, Sverdlovsk Region (Gerasimenko, Reznikova, 1968) and Primorye Territory (Probatova, 2014).

Tetraploid $(4 x), x=12$.

\section{Conclusion}

To date, the chromosome numbers of 49 invasive and potentially invasive plant species distributed in the Republic of Altai were examined. The data for 10 species are presented in this study. In the studied species, four are diploids. Six of them are polyploids, namely Solanum nigrum, Setaria faberi, Picris hieracioides, Malva verticillata, Oxalis dillenii. Among 10 investigated species, the most active on the territory of the Altai Republic are hexaploid Malva verticillata, tetraploid Oxalis dillenii and diploid Lolium perenne. New tetraploid cytotype for Picris hieracioides was identified.

\section{Acknowledgements}

The study was carried out within the framework of the Scientific Program № AAAA-A17-117012610055-3 of the Central Siberian Botanical Garden SB RAS.

\section{REFERENCES / ЛИТЕРАТУРA}

An'kova T. V., Zykova E. Yu., Ebel A. L. 2019. IAPT/IOPB chromosome data 31. Ed. K. Marhold. Taxon 68: 1375-1376; E6-E7. DOI: 10.1002/tax.12176

Chepinoga V. V., Gnutikov A. A., Enushchenko I. V. 2010. IAPT/IOPB chromosome data 9. Ed. K. Marhold. Taxon 59(4): 1298-1299; E1-E5.

Doležel J., Greilhuber J., Lucretti S., Meister A., Lysák M. A., Nardi L., Obermayer R. 1998. Plant genome size estimation by flow cytometry: Inter-laboratory comparison. Annals of Botany 82 Supp A: 17-26. DOI: 10.1006/ anbo.1998.0730

Doležel J., Greilhuber J., Suda J. 2007. Estimation of nuclear DNA content in plants using flow cytometry. Nature Protocols 2(9): 2233-2244. DOI: 10.1038/nprot.2007.310 
Doležel J., Sgorbati S., Lucretti S. 1992. Comparison of three DNA fluorochromes for flow cytometric estimation of nuclear DNA content in plants. Physiologia Plantarum 85(4): 625-631. DOI: 10.1111/j.1399-3054.1992.tb04764.x.

Ebel A. L. 2008. New and rare species of flowering plants to the flora of Altai mountain country. Turczaninowia 11, 4: 77-85. [In Russian] (Эбель A. Л. Новые и редкие виды цветковых растений для флоры Алтайской горной страны // Turczaninowia, 2008. T. 11, № 4. C. 77-85). URL: http://old.ssbg.asu.ru/turcz/turcz4_08_77_85.pdf

Ebel A. L., Strelnikova T. O., Kupriyanov A. N., Anenkhonov O. A., Ankipovich E. C., Antipova E. M., Verkhozina A. V., Efremov A. N., Zykova E. Yu., Mikhailova S. I., Plikina N. V., Ryabovol S. V., Silantyeva M. M., Stepanov N. V., Terekhina T. A., Chernova O. D., Shaulo D. N. 2014. Invasive and potential invasive species of Siberia. Byull. Glavn. bot. sada (Moscow) [Bulletin of the Main Botanical Garden] 1(200): 52-61. [In Russian] (Эбель A. Л., Стрельникова Т. О., Куприянов А. Н., Аненхонов О. А., Анкипович Е. С., Антипова Е. М., Верхозина А. В., Ефремов А. Н., Зыкова Е. Ю., Михайлова С. И., Пликина Н. В., Рябовол С. В., Силантьева М. М., Степанов Н. В., Терехина Т. А., Чернова О. Д., Шауло Д. Н. Инвазионные и потенциально инвазионные виды Сибири // Бюл. Глав. ботан. сада, 2014. № 1 (вып. 200). С. 52-61).

Ebel A. L., Verkhozina A. V., Zykova E. Yu., Strelnikova T. O., Khrustaleva I. A., Sheremetova S. A., Mikhailova S. I., Ebel T. V., Murashko V. V. 2018. New findings of alien plant species in Siberia. Sist. Zametki Mater. Gerb. Krylova Tomsk. Gosud. Univ. [Systematic notes on the materials of P. N. Krylov Herbarium of Tomsk state University] 118: 50-63. [In Russian] (Эбель А. Л., Верхозина А. В., Зыкова Е. Ю., Стрельникова Т. О., Хрусталева И. А., Шереметова С. А., Михайлова С. И., Эбель Т. В., Мурашко В. В. Новые находки чужеродных видов растений в Сибири // Сист. зам. Герб. Томск. ун-та, 2018. № 118. С. 50-63. DOI: 10.17223/20764103.118.4

Ebel A. L., Zykova E. Yu., Verkhozina A. V., Mikhaylova S. I., Prokopyev A. S., Strelnikova T. O., Sheremetova S. A., Khrustaleva I. A. 2016. New data on distribution of alien and synanthropic plant species in Siberia. Sist. Zametki Mater. Gerb. Krylova Tomsk. Gosud. Univ. [Systematic notes on the materials of P. N. Krylov Herbarium of Tomsk state University] 114: 16-37. [In Russian] (Эбель А. Л., Зыкова Е. Ю., Верхозина А. В., Михайлова С. И., Прокопьев А. С., Стрельникова Т. О., Шереметова С. А., Хрусталева И. А. Новые сведения о распространении в Сибири чужеродных и синантропных видов растений // Сист. зам. Герб. Томск. ун-та, 2016. № 114. С. 16-37). DOI: $10.17223 / 20764103.114 .4$

Geltman D. V. 1989. Picris L. In: Flora yevropeyskoy chasti SSSR [Flora of the European part of the USSR]. Vol. 8. Leningrad: Nauka. Pp. 32-34. [In Russian] (Гельтман Д. В. Picris L. // Флора европейской части СССР. Т. 8. Л.: Наука, 1989. С. 32-34).

Gerasimenko I. I., Reznikova S. A. 1968. A cytological investigation of genus Solanum L. Bot. Zhurn. (Moscow \& Leningrad) 53(4): 505-513. [In Russian] (Герасименко И. И., Резникова С. А. Цитологическое изучение видов рода Solanum L. // Бот. журн., 1968. Т. 53, № 4. С. 505-513).

Gubanov I. A. 1994. Inula L. In: Flora yevropeyskoy chasti SSSR [Flora of the European part of the USSR]. Vol. 7. St. Petersburg: Nauka. Pp. 80-87. [In Russian] (Губанов И. A. Inula L. // Флора европейской части СССР. Т. 7. Л.: Наука, 1994. С. 80-87).

Hassler M. 2020. World Plants: Synonymic Checklists of the Vascular Plants of the World (version Nov 2018). In: Species 2000 \& ITIS Catalogue of Life, 2020-08-01 Beta. Eds. Y. Roskov, G. Ower, T. Orrell, D. Nicolson, N. Bailly, P. M. Kirk, T. Bourgoin, R. E. DeWalt, W. Decock, E. van Nieukerken, L. Penev. Species 2000: Naturalis, Leiden, the Netherlands. URL: www.catalogueoflife.org/col (Accessed 15 December 2020).

Ikonnikov S. S. 2004. Psammophiliella Ikonn. In: Flora Vostochnoy Yevropy [Flora of Eastern Europe]. Vol. 11. Moscow; St. Petersburg: Nauka. Pp. 265-266. [In Russian] (Иконников С. С. Psammophiliella Ikonn. // Флора Bocточной Европы. Т. 11. М.; СПб.: Наука, 2004. С. 265-266).

Kotov M. I. 1979. Eruca L. In: Flora yevropeyskoy chasti SSSR [Flora of the European part of the USSR]. Vol. 4. Leningrad: Nauka. P. 46. [In Russian] (Котов М. И. Eruca L. // Флора европейской части СССР. Т. 4. Л.: Наука, 1979. C. 46).

Kovtonyuk N. K. 1993. Psammophiliella Ikonn. In: Flora Sibiri [Flora of Siberia]. Vol. 6. Novosibirsk: Nauka. P. 81. [In Russian] (Ковтонюк Н. К. Рsammophiliella Ikonn. // Флора Сибири. Т. 6. Новосибирск: Наука, 1993. C. 81).

Krasnikov A. A., Lomonosova M. N. 1990. Chromosome numbers in representatives of some families of vascular plants in the flora of the Novosibirsk region. I. Bot. Zhurn. (Moscow \& Leningrad) 75(1): 116-118. [In Russian] (Красников А. А., Ломоносова М. Н. Хромосомные числа представителей из некоторых семейств флоры Новосибирской области, 1 // Бот. журн., 1990. Т. 75, № 1. С. 116-118).

Krylov P. N. 1904. Inula L. In: Flora Altaya i Tomskoy gubernii [Flora of Altai and Tomsk province]. Vol. 3. Tomsk. Pp. 603-606. [In Russian] (Крылов П. Н. Inula L. // Флора Алтая и Томской губернии. Т. 3. Томск, 1904. C. 603-606).

Krylov P. N. 1907. Solanum L. Flora Altaya i Tomskoy gubernii [Flora of Altai and Tomsk province]. Vol. 4. Tomsk. Pp. 917-919. [In Russian] (Крылюв П. Н. Solanum L. // Флора Алтая и Томской губернии. Т. 4. Томск, 1907. C. 917-919). 
Krylov P. N. 1928. Lolium L. In: Flora Zapadnoy Sibiri [Flora of Western Siberia]. Vol. 2. Tomsk: Tomsk University Press. Pp. 343-344. [In Russian] (Крылов П. Н. Lolium L. // Флора Западной Сибири. Т. 2. Томск: изд-во ТГУ, 1928. С. 343-344).

Krylov P. N. 1939. Solanum L. In: Flora Zapadnoy Sibiri [Flora of Western Siberia]. Vol. 10. Tomsk: Tomsk University Press. Pp. 2405-2408. [In Russian] (Крылов П. Н. Solanum L. // Флора Западной Сибири. Т. 10. Томск: изд-во ТГУ, 1939. С. 2405-2408).

Krylov P. N. 1949. Inula L. In: Flora Zapadnoy Sibiri [Flora of Western Siberia]. Vol. 11. Tomsk: Tomsk University Press. Pp. 2704-2712. [In Russian] (Крылов П. Н. Inula L. // Флора Западной Сибири. Т. 11. Томск: изд-во ТГУ, 1949. С. 2704-2712).

Lomonosova M. N. 1997. Picris L. In: Flora Sibiri [Flora of Siberia]. Vol. 13. Novosibirsk: Nauka. Pp. $253-254$. [In Russian] (Ломоносова М. Н. Picris L. // Флора Сибири. Т. 13. Новосибирск: Наука, 1997. С. 253-254).

Lomonosova M. N., Sukhorukov A. P. 2000. The floristic findings in South Siberia. Turczaninowia 3, 4: 64-66. [In Russian] (Ломоносова М. Н., Сухоруков А. П. Флористические находки в Южной Сибири // Turczaninowia, 2000. T. 3, № 4. C. 64-66). URL: http://old.ssbg.asu.ru/turcz/p64-66.pdf

Lomonosova M. N., Zykova E. Yu., An'kova T. V. 2018. Chromosome numbers of invasive species of the Altai Republic flora. II. Turczaninowia 21, 4: 63-72. DOI: 10.14258/turczaninowia.21.4.7

Magulaev A. Yu. 1974. Chromosome numbers of some plants of the North Caucasus. In: Flora i rastitelnost Vostochnogo Kavkaza [Flora and vegetation of the Eastern Caucasus]. Ordzhonikidze. Pp. 116-117. [In Russian] (Магулаев A. Ю. Хромосомные числа некоторых растений Северного Кавказа // Флора и растительность Восточного Кавказа. Орджоникидзе, 1974. С. 116-117).

Magulaev A. Yu. 1984. Cytotaxonomic study in some flowering plants of the North Caucasus. Bot. Zhurn. (Moscow \& Leningrad) 69(4): 511-517. [In Russian] (Магулаев А. Ю. Цитотаксономическое изучение некоторых цветковых растений Северного Кавказа // Бот. журн., 1984. Т. 69, № 4. С. 511-517).

Mikhaylova S. I., Ebel A. L. 2016. Malva verticillata L. In: Chyernaya kniga flory Sibiri [Black book of the flora of Siberia]. Novosibirsk: GEO Publ. Pp. 280-284. [In Russian] (Михайлова С. И., Эбель А. Л. Malva verticillata L. - Мальва мутовчатая // Черная книга флоры Сибири. Новосибирск: Академическое изд-во «Гео», 2016. С. 280-284).

Nikiforova O. D. 1994. Eruca L. In: Flora Sibiri [Flora of Siberia]. Vol. 7. Novosibirsk: Nauka. P. 137. [In Russian] (Никифорова О. Д. Eruса L. // Флора Сибири. Т. 7. Новосибирск: Наука, 1994. С. 137).

Petrova O. A. 1968. Chromosomal composition of some cereals of the flora of Ukraine in connection with the conditions of their growth. In: Biologicheskaya nauka v universitetakh i pedagogicheskikh institutakh Ukrainy za 50 let [Biological science in universities and pedagogical institutes of Ukraine for 50 years]. Kharkov. Pp. 37-39. [In Russian] (Петрова O. A. Хромосомный состав некоторых злаков флоры Украины в связи с условиями их произрастания // Биологическая наука в университетах и педагогических институтах Украины за 50 лет. Харьков, 1968. С. 37-39).

Poyarkova A. I. 1981. Solanum L. In: Flora yevropeyskoy chasti SSSR [Flora of the European part of the USSR]. Vol. 5. Leningrad: Nauka. Pp. 181-189. [In Russian] (Пояркова A. И. Solanum L. // Флора европейской части СССР. Т. 5. Л.: Наука, 1981. С. 181-189).

Probatova N. S. 2014. Chromosome numbers in vascular plants of the Primorye Territory (Russian Far East). Vladivostok: Dalnauka, 343 pp. [In Russian] (Пробатова Н. С. Хромосомные числа сосудистых растений Приморского края. Владивосток: Дальнаука, 2014. 343 с.).

Probatova N. S., Barkalov V. Yu., Stepanov N. V. 2017a. Chromosome numbers in some vascular plant species from Siberia and the Russian Far East. Botanica Pacifica. A journal of plant science and conservation 6(1): 51-55. DOI: $10.17581 /$ bp.2017.06103

Probatova N. S., Kazanovsky S. G., Rudyka E. G. 2014a. IAPT/IOPB chromosome data 17. Eds. K. Marhold, I. Breitweiser. Taxon 63(5): 1153-1154; E23-E24. URL: www.iapt-taxon.org/files/iopb/IAPT_IOPB_Chr_data17.pdf

Probatova N. S., Kazanovsky S. G., Rudyka E. G., Seledets V. P., Nechaev V. A. 2012. IAPT/IOPB chromosome data 13. Ed. K. Marhold. Taxon 61(4): 889-902; E34-E42. DOI: 10.1002/tax.614023

Probatova N. S., Krivenko D. A., Barkalov V. Yu. 2017b. Further chromosome studies on the flora of Sakhalin and the Kurils, with additions from adjacent regions of the Russian Far East. Botanica Pacifica. A journal of plant science and conservation 6(2): 69-75. DOI: 10.17581/bp.2017.06209

Probatova N. S., Seledets V. P., Rudyka E. G. 2014b. IAPT/IOPB chromosome data 18. Ed. K. Marhold. Taxon 63(6): 1391-1392; E27-E30. URL: https://www.iapt-taxon.org/files/iopb/IAPT_IOPB_Chr_data17.pdf

Probatova N. S., Seledets V. P., Rudyka E. G., Gnutikov A. A., Kozhevnikova Z. V., Barkalov V. V. 2009. IAPT/ IOPB chromosome data 8. Ed. K. Marhold. Taxon 58(4): 1284-1288; E11-E20. URL: www.iapt-taxon.org/files/iopb/ IAPT_IOPB_Chr_data8.pdf

Probatova N. S., Shatokhina A. V., Rudyka E. G. 2005. Chromosome numbers of some dicotyledons of the flora of the Amur Region. Bot. Zhurn. (Moscow \& St. Petersburg) 90(5): 779-792. [In Russian] (Пробатова Н. С., Ша- 
тохина A. В., Рудыка Э. Г. Числа хромосом некоторых двудольных флоры Амурской области // Бот. журн., 2005. T. 90, № 5. C. 779-792).

Probatova N. S., Sokolovskaya A. P. 1983. Chromosome numbers in Adoxaceae, Chloranthaceae, Cupressaceae, Juncaceae, Poaceae. Bot. Zhurn. (Moscow \& St. Petersburg) 68(12): 1683-1684. [In Russian] (Пробатова H. C., Соколовская А. П. Хромосомные числа: Adoxaceae, Chloranthaceae, Cupressaceae, Juncaceae, Роасеае // Бот. журн., 1983. Т. 68, № 12. C. 1683-1684).

Punina E. O., Myakoshina Y. A., Dobryakova K. S., Nosov N. N., Rodionov A. V. 2013. A karyological study of Grasses (Poaceae) of Altai. I. Turczaninowia 16, 2: 127-133. [In Russian] (Пунина Е. О., Мякоиина Ю. А., Добрякова К. С., Носов Н. Н., Родионов А. В. Кариологическое исследование злаков (Роасеае) Алтая и Алтайского края. Сообщение I // Turczaninowia, 2013. T. 16, № 2. С. 127-133).

Pyak A. I., Ebel A. L. 2001. Materials to flora of Altai Mountains. Turczaninowia 4, 1-2: 86-94. [In Russian] (Irא А. И., Эбель А. Л. Материалы к флоре Алтая // Turczaninowia, 2001. Т. 4, № 1-2. С. 86-94).

Pyak A. I., Ebel A. L., Ebel T. V. 2000. New and rare plants for flora of Altai region and Republic of Altai. Krylovia 2(1): 67-72. [In Russian] (Пяк А. И., Эбель А. Л., Эбель Т. В. Новые и редкие виды растений во флоре Алтайского края и Республики Алтай // Krylovia, 2000. Т. 2, № 1. С. 67-72).

Rice A., Glick L., Abadi S., Einhorn M., Kopelman N., Salman-Minkov A., Mayzel J., Chay O., Mayrose I. 2015. The Chromosome Counts Database (CCDB) - a community resource of plant chromosome numbers. New Phytol. 206(1): 19-25. URL: http://ccdb.tau.ac.il (Accessed 31 May 2018).

Rostovtseva T. S. 1983. Chromosome numbers of some species of the family Asteraceae. II. Bot. Zhurn. (Moscow \& Leningrad) 68(5): 660-664. [In Russian] (Ростовцева T. C. Числа хромосом некоторых видов семейства Аsteraceae - 2 // Бот. журн., 1983. Т. 68, № 5. С. 660-664).

Sakiroglu M., Kaya M. M. 2012. Estimating genome size and confirming ploidy levels of wild tetraploid alfalfa (Medicago sativa subsp. varia) using flow cytometry. Turkish Journal of Field Crops 17, 2:151-156.

Shaulo D. N., Zykova E. Yu., Drachev N. S., Kuzmin I. V., Doronkin V. M. 2010. Floristic findings in West and Middle Siberia. Turczaninowia 13, 3: 77-91. [In Russian] (Шауло Д. Н., Зыкова Е. Ю., Драчев Н. С., Кузымин И. В., Доронькин В. М. Флористические находки в Западной и Средней Сибири // Turczaninowia, 2010. Т. 13, № 3. С. 77-91).

Shouliang Ch., Phillips S. M. 2006. Setaria P. Beauv. In: Flora of China. Vol. 22. Pp. 531-537.

Silantyeva M. M. 2013. Konspekt flory Altayskogo kraya [Check-list of the flora of Altayskiy krai]. Second edition. Barnaul: Altai State University Publ. 520 pp. [In Russian] (Силантьева М. М. Конспект флоры Алтайского края. 2-е изд. Барнаул: Изд-во АГУ, 2013. 520 с.).

Slovák M., Vít P., Urfus T., Suda J. 2009. Complex pattern of genome size variation in a polymorphic member of the Asteraceae. Journal of Biogeography 36(2): 372-384. DOI: 10.1111/j.1365-2699.2008.02005.x

Studenikina E. Yu. 1999. Vysshiye sosudistyye rasteniya flory Biye-Katunskogo mezhdurechya v predelakh predgoriy i nizkogoriy Altaya [Higher vascular plants of the flora of the Bie-Katun interfluve within the foothills and low mountains of Altai]. Barnaul. 121 pp. [In Russian] (Студеникина Е. Ю. Высшие сосудистые растения флоры Бие-Катунского междуречья в пределах предгорий и низкогорий Алтая. Барнаул, 1999. 121 с.).

Tzvelev N. N. 1996. Xanthoxalis Small. In: Flora yevropeyskoy chasti SSSR [Flora of the European part of the USSR]. Vol. 9. St. Petersburg: Nauka. Pp. 366-368. [In Russian] (Цвелев Н. Н. Xanthoxalis Small. // Флора европейской части СССР. Т. 9. Л.: Наука, 1996. С. 366-368).

Tzvelev N. N., Probatova N. S. 2019. Zlaki Rossii [Cereals of the Russia]. Moscow: KMK Scientific Publishing Association. 646 pp. [In Russian] (Цвелёв Н. Н., Пробатова Н. С. Злаки России. М.: Товарищество научных изданий КМК, 2019. 646 с.).

Vlasova N. V. 1996. Malva L. In: Flora Sibiri [Flora of Siberia]. Vol. 10. Novosibirsk: Nauka. Pp. 67-69. [In Russian] (Власова C. Н. Malva L. // Флора Сибири. T. 10. Новосибирск: Наука, 1996. С. 67-69).

Zolotukhin N. I. 1983. Adventive plants in the Altai Reserve. Bot. Zhurn. (Moscow \& Leningrad) 68(11): 15281533. [In Russian] (Золотухин Н. И. Адвентивные растения на территории Алтайского заповедника // Бот. журн., 1983. Т. 68, № 11. С. 1528-1533).

Zykova E. Yu. 2014. New records of alien species in the flora of the Republic of Altai. Byull. Moskovsk. Obshch. Isp. Prir., Otd. Biol. [Bull. Moscow Soc. Natur. Biol. Ser.] 119, 1: 80-81. [In Russian] (Зыкова Е. Ю. Новые находки адвентивных видов во флоре Республики Алтай // Бюл. МОИП. Отд. биол., 2014. Т. 119, вып. 1. С. 80-81).

Zykova E. Yu. 2015. Alien flora of the Republic of Altai. Rastitelnyy mir Aziatskoy Rossii [Plant Life of Asian Russia] 3(19): 72-87. [In Russian] (Зыкова E. Ю. Адвентивная флора Республики Алтай // Растительный мир Азиатской России, 2015. № 3(19). С. 72-87).

Zykova E. Yu. 2019. Findings of adventive species in the Republic of Altai. Byull. Moskovsk. Obshch. Isp. Prir., Otd. Biol. [Bull. Moscow Soc. Natur. Biol. Ser.] 124, 6: 66-68. [In Russian] (Зыкова Е. Ю. Находки адвентивных видов в Республике Алтай // Бюл. МОИП. Отд. биол., 2019. Т. 124, вып. 6. С. 66-68).

Zykova E. Yu., Ebel A. L., Ebel T. V., Sheremetova S. A. 2019. New findings of alien plants in the Republic of Altai. Turczaninowia 22, 1: 143-153. [In Russian] (Зыкова Е. Ю., Эбель А. Л., Эбель Т. В., Шереметова С. А. Но- 
вые находки адвентивных видов растений в Республике Алтай // Turczaninowia, 2019. Т. 22, № 1. С. 143-153). DOI: 10.14258/turczaninowia.22.1.11

Zykova E. Yu., Erst A. S. 2012. Floristic findings of some rare and alien species in Siberia. Turczaninowia 15, 4:

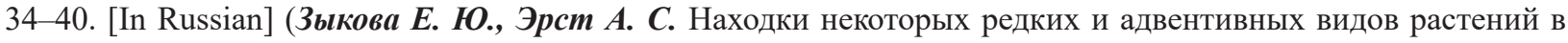
Сибири // Turczaninowia, 2012. Т. 15, № 4. С. 34-40).

Zykova E. Yu., An'kova T. V., Lomonosova M. N. 2020. Chromosome numbers of invasive and potentially invasive species in the flora of the Republic of Altai. III. Turczaninowia 23, 1: 133-139. DOI: 10.14258/turczaninowia.23.1.15

Zykova E. Yu., Lomonosova M. N., An'kova T. V. 2018. Chromosome numbers of invasive species of the Altai Republic flora: post 1. Turczaninowia 21, 1: 41-51. [In Russian] (Зыкова Е. Ю., Ломоносова М. Н., Анькова Т. В. Числа хромосом инвазионных видов во флоре Республики Алтай: сообщение 1 // Turczaninowia, 2018. T. 21, № 1. C. 41-51). DOI: 10.14258/turczaninowia.21.1. 